\title{
Attracting Birds to Your Yard
}

Birds capture the imagination of homeowners from all walks of life. A glance out a window during fall or spring may reveal a pinstriped blackpoll warbler busily feeding during a break from migratory flights that take it to places as far away as the boreal forests of Canada or the mountain forests of South America. Lifeless and cold winter days may be enhanced by the company of a flock of chickadees. A morning on the back porch may turn into a front seat for the first attempts at flight by recently hatched robins. Backyard habitats are important resources for many birds, and homeowners can take actions to increase the attractiveness of their yard for birds. Additionally, the same practices deemed desirable by birds can increase property values, improve aesthetics, help conserve energy costs with shade or insulation from strong winds, reduce the abundance of certain insect pests, and provide an enriching experience to observe and learn about the birds in your own backyard. This publication explores those practices and offers guidance on making the most of your yard for wildlife.

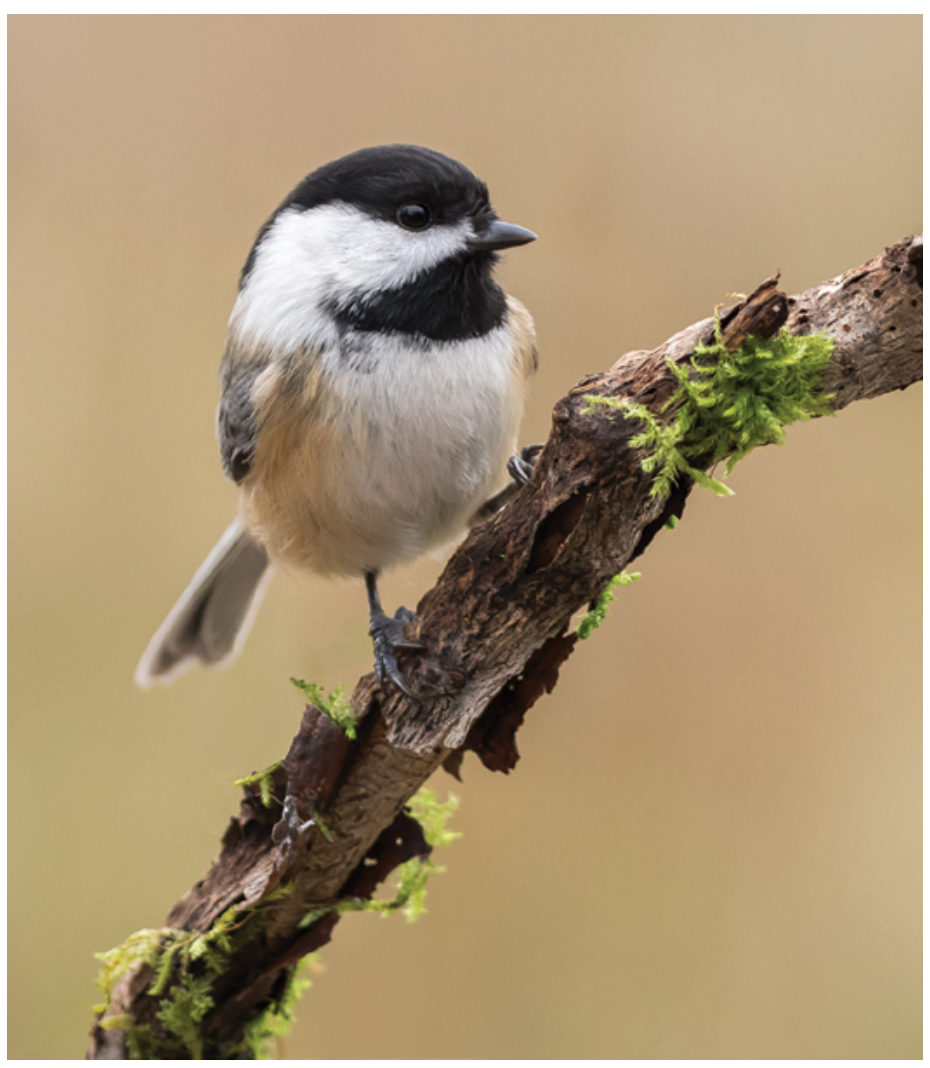

Black-capped chickadee. Photo by JerryGrugin/Thinkstock.com.

\section{Key Considerations}

Provide food through plantings of native seed, fruit, or nectar producing plants or by providing the right types of feeders during each season.

Integrate water sources into landscapes with bird baths, water drips, or small ponds.

Create places to provide shelter to raise young, to escape predators, or stay warm in dense shrubs, grasses, wildflowers, or nest boxes.

- Structure landscaping to create a layered-effect: tall trees along the perimeter, descending to shorter trees, shrubs, and then to grasses and flowers.

\section{Creating bird habitat in your yard}

Whether they live in a national forest or on a city street, all birds need four things from their habitats: food, water, shelter, and space. Well-designed landscapes that incorporate the recommendations provided here can satisfy all these habitat elements and attract a rich diversity of birds.

Landscape more, mow less. Turfgrasses, or lawns, are an important landscape element for certain aesthetics and to provide a place for friends and family to gather and play. But turfgrass has no functional value to wildlife and can often have a negative ecological impact due to the fertilizers and herbicides used to maintain it. Find a balance in the yard, ensuring there are enough grassy areas to throw a baseball or stare at the stars, but repurpose the balance of the yard for landscaping with trees, shrubs, grasses, and wildflowers that will be aesthetically pleasing and attractive to birds.

Build upon existing landscaping components. Whether moving into a new home or looking to attract more birds to a place owned for years, the building blocks of a wildlife-friendly yard might be already present. For instance, dense trees lining a property boundary make a great starting point for layering trees, shrubs, grasses, and flowers into the middle of the yard. Add shrubs to the perimeter of an established flower garden, while also incorporating additional nectar sources from wildflowers for hummingbirds or seed-bearing wildflowers for finches.

\section{IOWA STATE UNIVERSITY}

Extension and Outreach 
Choose plants for shelter. Birds need shelter for nesting, resting, and avoiding harsh weather. The kind of shelter a bird needs varies with the season and bird. To attract nesting birds during summer, provide a diversity of shrubs and sheltered ground areas to accommodate those that prefer to nest in high places or near the ground. Shrubs with horizontal branches, like crabapples or flowering dogwood, make great nesting places. Clusters of undisturbed flowers and grasses create important ground nesting areas too. Choose a variety of trees and shrubs that reach varying heights for more aerobatic nesters like the Baltimore oriole. Protect winter residents against storms and winds by growing plants that will provide structure during the winter months, like evergreen trees and dense shrubs, or leave the residual growth of last year's grasses and wildflowers until the spring thaw.

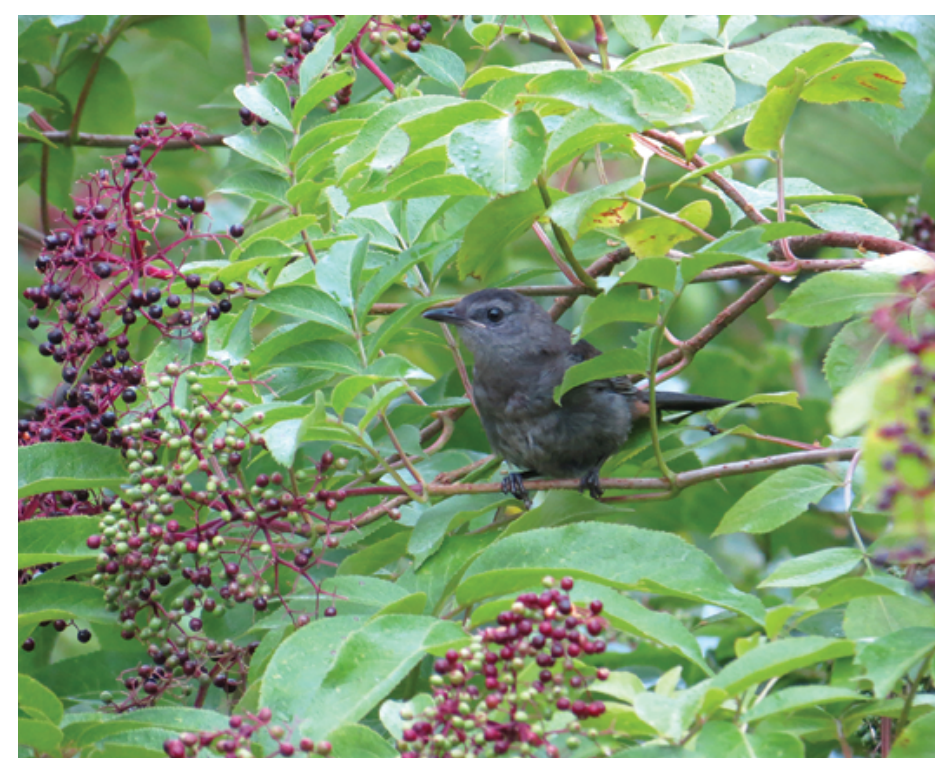

Native shrubs, such as the elderberry pictured here, provide nesting structure, roosting space, escape cover, and food for a long list of birds, including this gray catbird. Photo by Karl Jungbluth.

Grow the food birds want. Fruit, nut, and seed producing plants are a foundation of wildlife landscaping. From mature oaks and hickories that produce nuts eaten by blue jays, woodpeckers, nuthatches, and chickadees, to the serviceberries that hold copious amounts of fruit for robins and waxwings, many plants double as a food source and a place for birds to nest, rest, and roost.

Keep insect-eaters, like migrating warblers, vireos, flycatchers, and tanagers or the young of many familiar backyard birds, fed by planting flowering shrubs and plants that attract beneficial insects. Many long-distance migrants that rely on fruits and insects during migration have been declining because of habitat loss, so extra work in the yard to host these species can help their populations and make a yard unique. Table 1 provides advice on native shrubs to plant for birds and the resources at the end of this article provide places to look for the right native flowers and grasses for a landscape.

Table 1. Native shrubs to attract birds to lowa yards

\begin{tabular}{|c|c|c|c|}
\hline Species & Food & Nesting & Winter \\
\hline $\begin{array}{l}\text { American plum } \\
\text { (Prunus americana) }\end{array}$ & + & ++ & ++ \\
\hline $\begin{array}{l}\text { Arrowwood } \\
\text { (Viburnum dentatum) }\end{array}$ & ++ & + & + \\
\hline $\begin{array}{l}\text { Blackhaw } \\
\text { (Viburnum prunifolium) }\end{array}$ & + & + & + \\
\hline Chokeberry (Aronia spp.) & + & ++ & + \\
\hline $\begin{array}{l}\text { Common chokecherry } \\
\text { (Prunus virginia) }\end{array}$ & ++ & + & \\
\hline Crabapple (Malus spp.) & + & + & \\
\hline Elderberry (Sambucus spp.) & ++ & & \\
\hline $\begin{array}{l}\text { Gray dogwood } \\
\text { (Cornus racemosa) }\end{array}$ & ++ & + & + \\
\hline $\begin{array}{l}\text { Hazelnut } \\
\text { (Corylus americana) }\end{array}$ & + & ++ & + \\
\hline $\begin{array}{l}\text { Highbush cranberry } \\
\text { (Viburnum trilobum) }\end{array}$ & + & & \\
\hline $\begin{array}{l}\text { Nannyberry } \\
\text { (Viburnum lentago) }\end{array}$ & + & & + \\
\hline $\begin{array}{l}\text { Ninebark } \\
\text { (Physocarpus abolifolius) }\end{array}$ & & ++ & ++ \\
\hline $\begin{array}{l}\text { Red-osier dogwood } \\
\text { (Cornus sericea) }\end{array}$ & ++ & ++ & + \\
\hline $\begin{array}{l}\text { Serviceberry } \\
\text { (Amerlachier spp.) }\end{array}$ & ++ & & \\
\hline $\begin{array}{l}\text { Silky dogwood } \\
\text { (Cornus amomum) }\end{array}$ & + & + & + \\
\hline Viburnums (Viburnum spp.) & ++ & + & \\
\hline
\end{tabular}

Create layers of vegetation within the yard. Begin with taller trees along the perimeter of the yard and work inward with shorter trees, shrubs, and finally native bunch grasses and wildflowers. This stair-step of vegetation creates an 

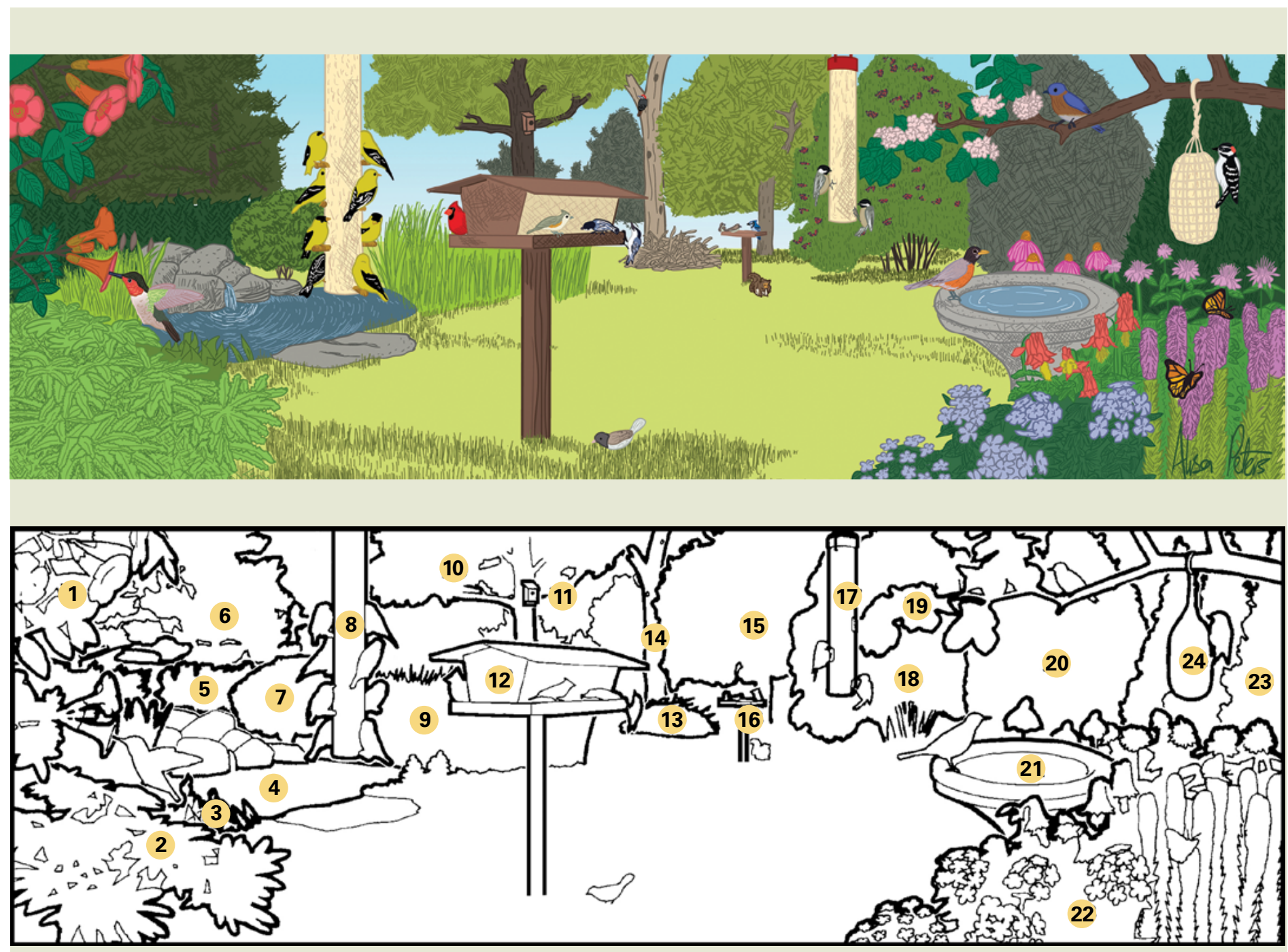

1. Trumpet vine

2. Maidenhair fern

3. Aquatic plants

4. Backyard pond

5. Low conifers

6. White pine
7. Red-osier dogwood

8. Thistle feeder

9. Native bunch grasses

10. Oak tree

11. Bird house

12. Hopper feeder
13. Brush pile

14. Dead tree (snag)

15. Apple tree

16. Platform feeder

17. Tube feeder

18. Elderberry
19. Hawthorn

20. Chokecherry

21. Bird bath

22. Pollinator garden

23. Arborvitae

24. Suet feeder

Combining all the right landscape elements with the right mix of feeders, shelter, and water sources will ensure a diverse suite of birds find what they need to call a backyard home.

aesthetically pleasing look and is sure to provide nesting, resting, and feeding areas. The leading edge of this layout is often an ideal spot to place bird feeders, because there is plenty of ground cover in place, along with shrubs and low trees nearby for birds to quickly land before or after visiting a food source. A similar layering effect can be established on a smaller scale around trees in the middle of the yard. In any spot, be sure to consider available light, water, soil type, soil $\mathrm{pH}$, and other site requirements in selecting and laying out landscape plants. 

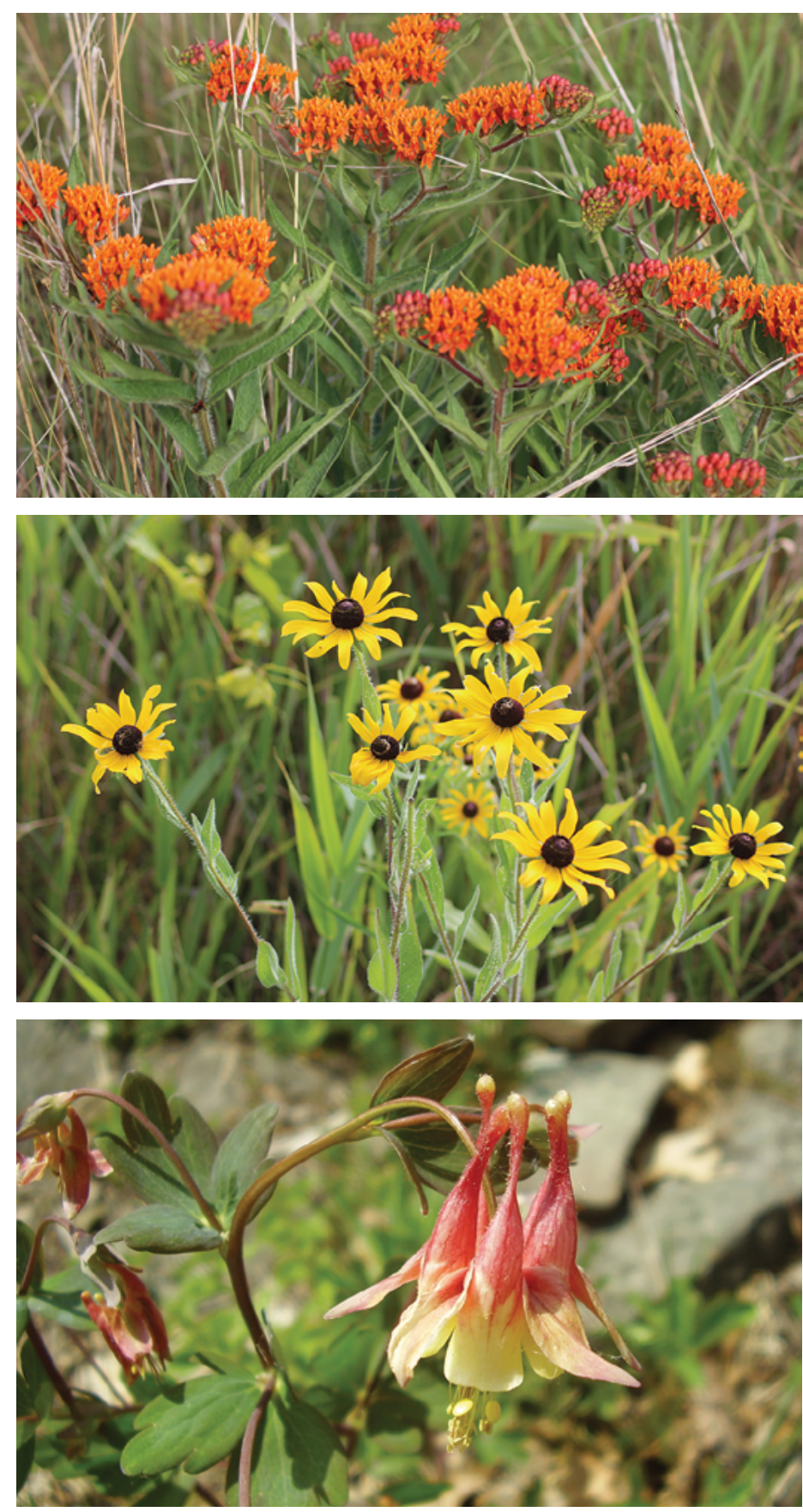

Native wildflowers, such as butterfly milkweed (top; Asclepias tuberosa), black-eyed susan (middle; Rudbeckia hirta), and columbine (bottom; Aquilegia spp.), are important elements of bird-friendly landscapes. The right mix of native flowers can provide important annual sources of nectar, seeds, or cover for birds and bring seasonal flushes of color to your yard. Hundreds of species of flowers are native to lowa. A few common bird-friendly species include blazing star (Liatris spp.), cardinal flower (Lobelia cardinalis), coreopsis (Coreopsis spp.), orange jewelweed (Impatiens capensis), purple coneflower (Echinacea spp.), wild bergamot (Monarda fistulosa), and wood lily (Lilium philadelphicum). See the references at the end of this publication for more information on finding native flowers and selecting the right species for the soils and sunlight in your yard. Photos by A. Janke.

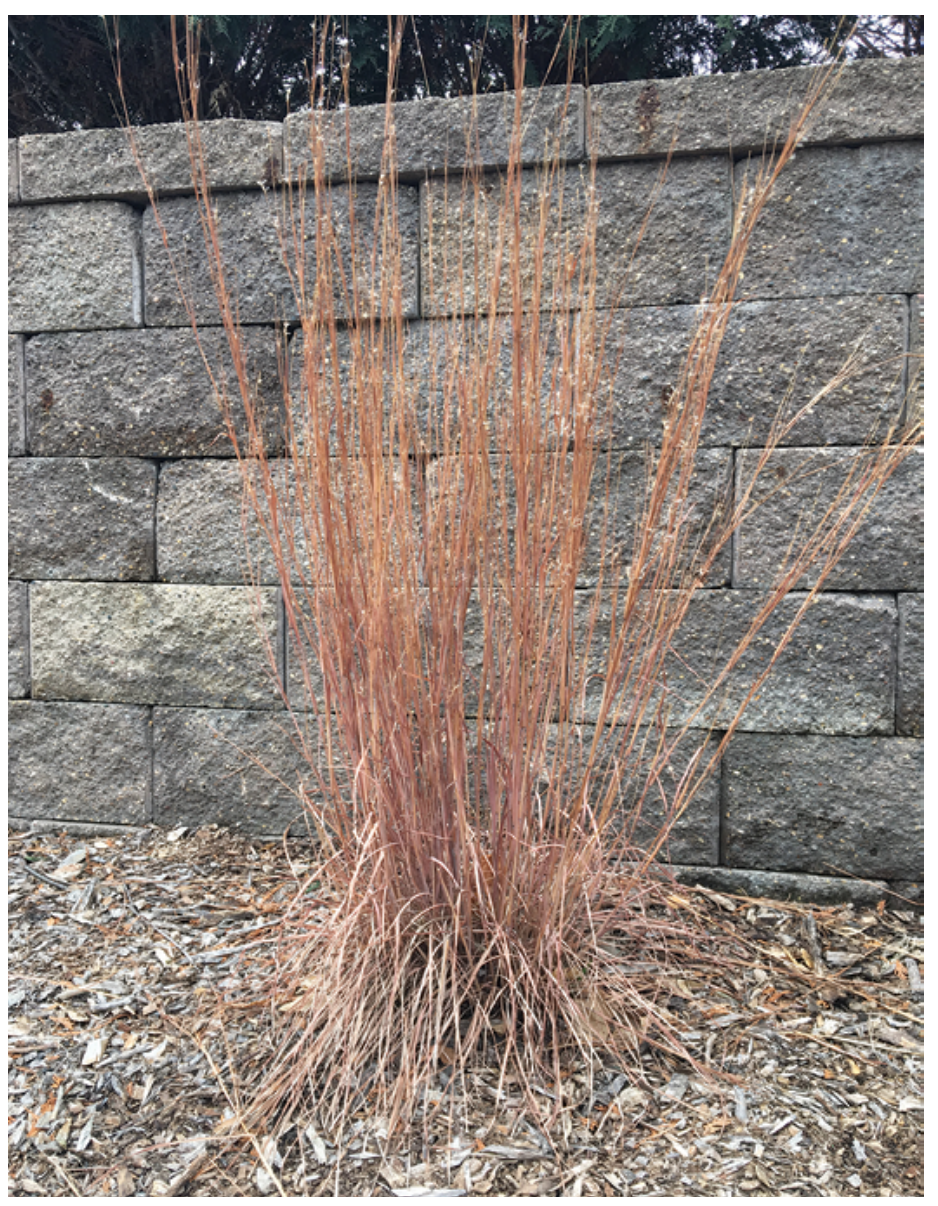

Native bunch grasses, like this little bluestem (Schizachyrium scoparium) are an important part of bird-friendly landscapes throughout the year when left standing during the winter. The grasses can provide cover for ground-dwelling birds, attract insects for food sources, and produce seeds some birds eat. Other common native bunch grass species in lowa include big bluestem (Andropogon gerardii), Indiangrass (Sorgastrum nutans), prairie dropseed (Sporobolus heterolepis), side-oats gramma (Bouteloua curtipedula) or switchgrass (Panicum virgatum). All these grasses thrive in moderate to full sunlight. Photo by A. Janke.

Use native plants whenever possible. To do the most for birds, plant a diversity of mostly native trees, shrubs, vines, grasses, and flowers. Birds found in lowa are adapted to finding and using native plants for nesting, roosting, and foraging and are most likely to find these familiar species most attractive. Similarly, native plants are best adapted to lowa environments and are therefore often a safe landscape investment. Most greenhouses have lists of locally adapted native plants and all recommendations in this article are plants native to lowa or the Midwest.

Add water sources. A consistent water source can be the difference between a very active yard and a yard with few birds. Nearly all birds are attracted to water. 
This is especially true with running water, which can be added using ready-made products or simple do-it-yourself techniques. For instance, cut a small hole in the bottom of a bucket, fill it with water, and hang it above a birdbath; the steady drip of fresh water into the birdbath makes it more attractive for drinking and bathing. Do the same with a hose or a commercial mister or dripper made with birds in mind. Much like bird feeders, it is worthwhile to offer water sources at different heights to accommodate the preferences of various species.

For a more adventurous approach, backyard ponds or rain gardens are attractive to birds and many other interesting wildlife species such as frogs, toads, and dragonflies.

They also allow some natural wetland vegetation to be incorporated into landscape designs. Ponds can be designed to fit the dimensions and landscaping scheme of just about any yard, and installation can be streamlined with a variety of materials designed expressly for this purpose. A waterfall can even be created using rocks and a large aquarium pump to circulate pond water over the rocks. During winter, when open water becomes scarce in lowa, a specially designed heater can be added to keep water available for birds on the coldest of days.

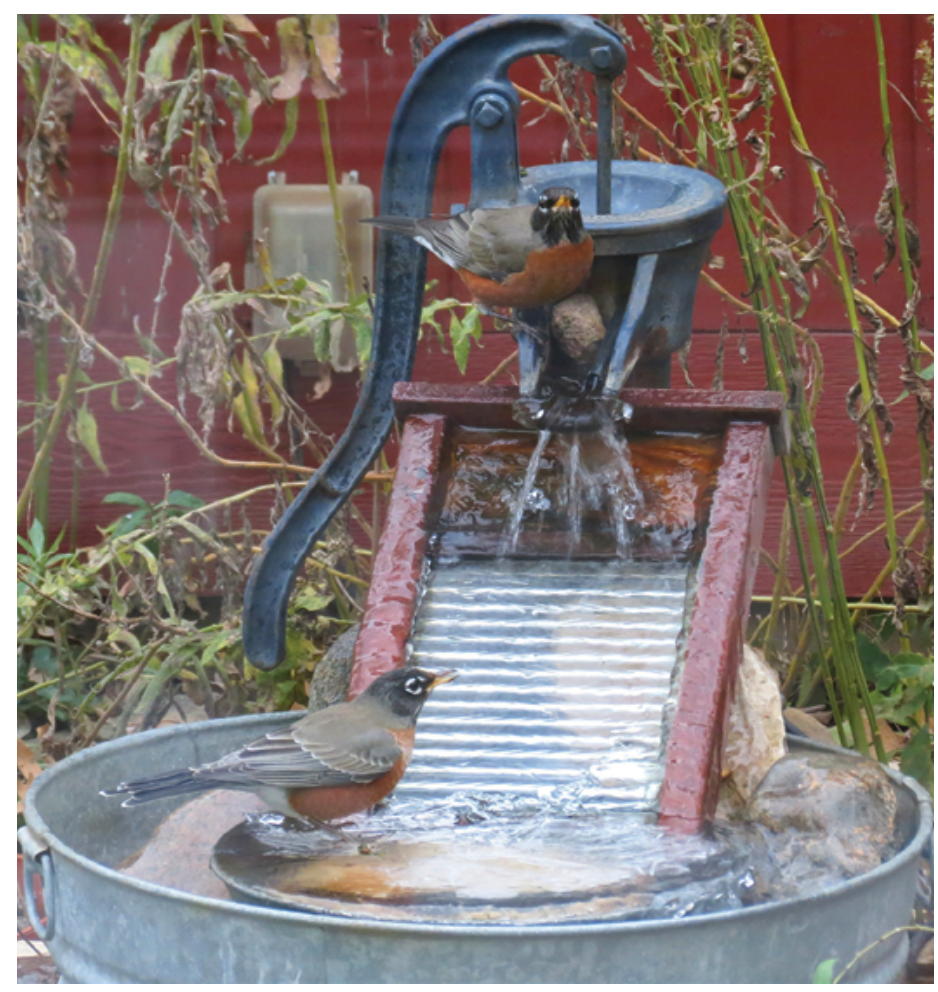

Water, especially running water, is vital for any bird-friendly yard. Commercial setups can be purchased, or existing components of a property can be assembled to form a unique water feature, such as this modified antique pump that has attracted American robins. Photo by Karl Jungbluth.
Fencing is essential. With the abundance of rabbits, deer, and other herbivores in yards across lowa, fencing will be needed - and lots of it - to keep many plantings safe. Protect woody plants until they reach a sufficient size and have a thick bark layer to guard against girdling. Otherwise, young shrubs and trees will be decimated by rabbits, deer, and other hungry critters. Fencing can be unsightly, but by installing it ahead of time, considerable frustration and expense on replacing plants damaged by mammals can be spared.

Incorporate dead or dying wood. Although it might go against traditional landscaping schemes, the presence of dead wood adds an important dimension to wildlifefriendly yards. The standing remnant of a dead tree trunk or a dead branch on a live tree can attract cavity nesters like woodpeckers, nuthatches, and chickadees. A small snag (5-10 feet high) is often enough. Best of all, aesthetics don't need to be abandoned; any of these dead-wood components can be hidden or positioned in such a way to attract birds without impacting the overall appearance of the yard. A rotting log or stump concealed in a wildflower garden allows additional feeding and escape habitat for ground-dwelling birds, including young birds who have just left the nest.

Install nest boxes. Over 20 bird species nest in holes in trees in lowa. Depending on the neighborhood's habitat, a nest box can attract many of these cavity-nesting birds to raise young right outside a home. In most lowa yards that have shrubs and shade trees, black-capped chickadees,

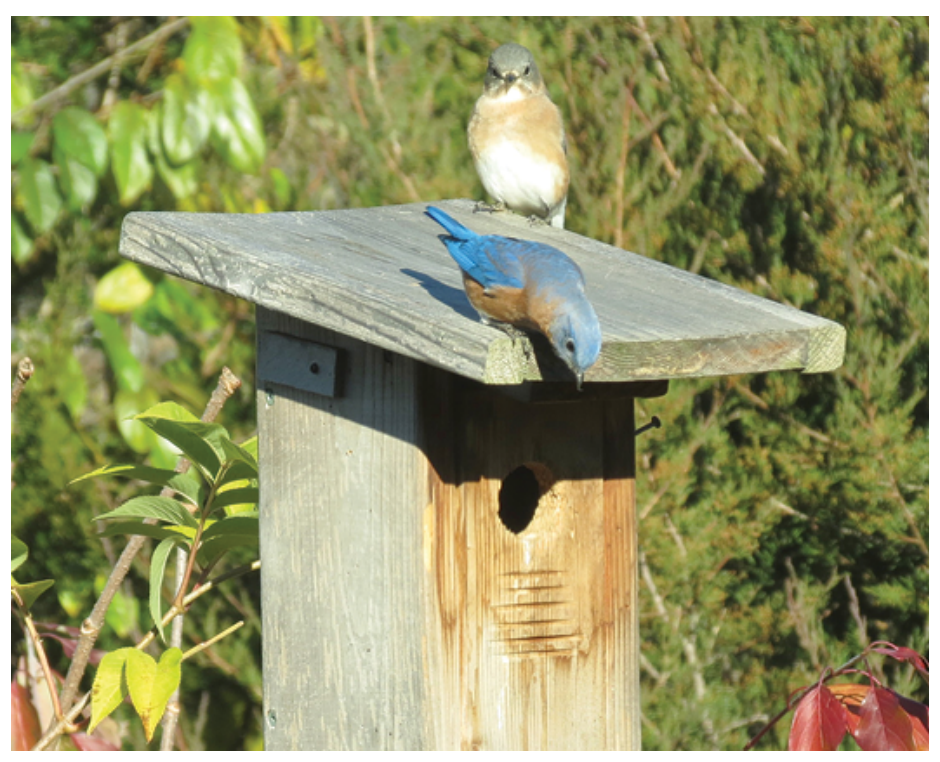

Nesting structures, such as this eastern bluebird box, attract specific birds to raise their young. Photo by Karl Jungbluth. 
Just let nature take its course? The option to "do nothing and just let it go natural" might sound appealing, but it usually doesn't produce bird-friendly results in the real world, especially in lowa's heavily altered landscape. Invasive plant species, which are aggressive, non-native, and capable of causing significant economic and environmental damage, pose problems for bird-friendly landscaping. The soil in lowa is generally very fertile, and invasive plants tend to spread and crowd out the desirable aspects. Many habitat patches in the state have a high quantity of growth but comparatively low quality as measured by a diversity of native plants and animals.

white-breasted nuthatches, house wrens, and downy woodpeckers are the most familiar nest box denizens. In the countryside and along open parks eastern bluebirds and tree swallows readily inhabit nest boxes. If water is nearby, a wood duck box is a good idea; a brood of wood duck hatchlings leaping from their nest box and following their mother to a pond or stream is one of the most captivating sights in the lowa outdoors.
Encourage your neighbors. Many of lowa's birds need more from their habitat than any typical home lot can provide. Work with neighbors to share knowledge and information about bird-friendly landscaping. If others adopt similar strategies, all yards in the neighborhood will reap the benefits of having habitat to entice even more birds. This is especially true when neighbors can connect existing patches of vegetation to create habitat corridors for birds.

Be creative and have fun with it! There are many approaches to building a bird friendly yard, and the finished product will depend on individual goals and the property's characteristics. Watching it all come together is very satisfying. For instance, after planting a shrub like a serviceberry, that plant will bloom beautifully in the spring, with waxwings, catbirds, and woodpeckers feeding on its fruit. Autumn will bring brilliant foliage, and cardinals, chickadees, and juncos will use it for shelter in the winter. Pay close attention to the habits and preferences of the birds as you start to make changes; close observation and learning will make a yard all the more welcoming for birds.
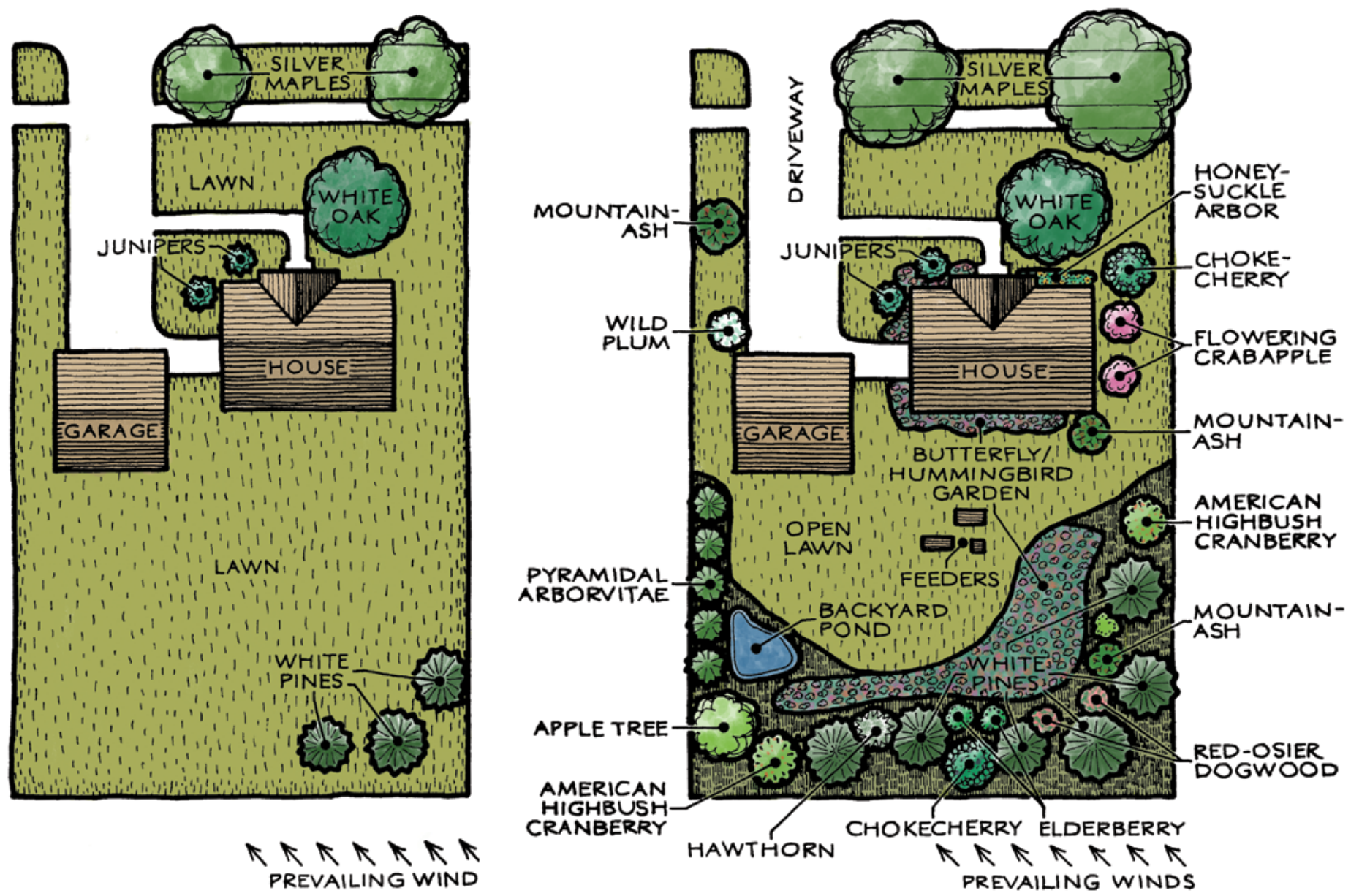

By landscaping more and mowing less, building on existing landscape components, choosing plants that produce food or provide structure, creating layers of vegetation, adding water to a landscape and following other recommendations in this article, any homeowner can take an unattractive yard for birds like the one on the left and turn it into a beautiful, bird-friendly lawn like the one on the right. 


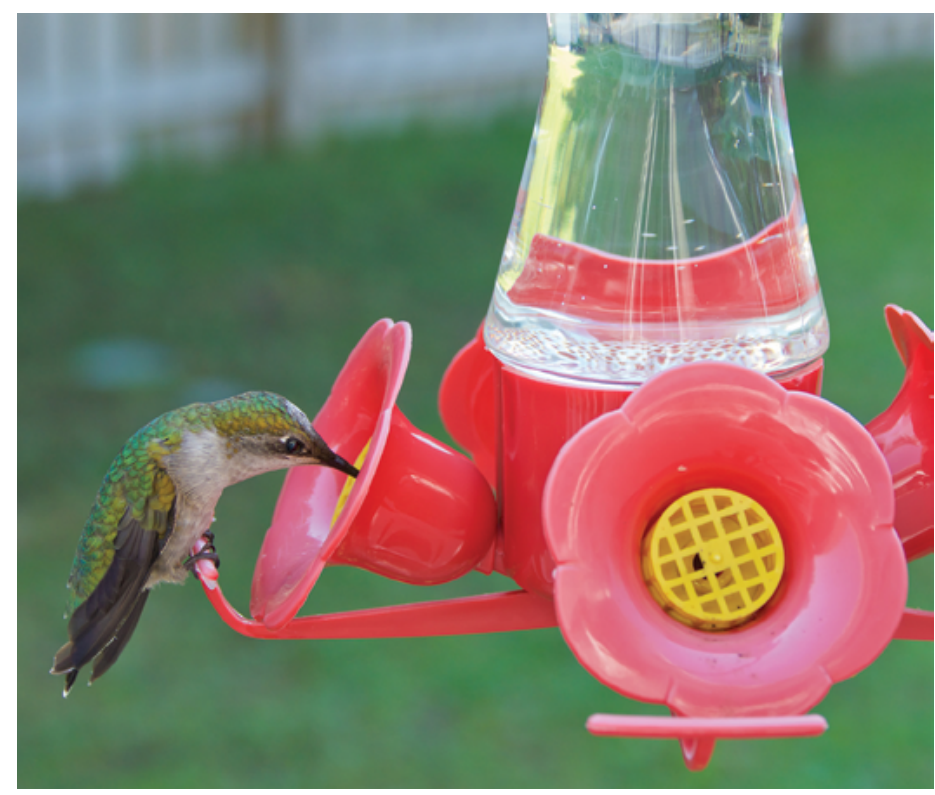

Ruby-throated hummingbird. Photo by msteve4770/Thinkstock.com.

\section{Attracting birds with feeders}

For centuries, wildlife enthusiasts have used feeders as a way to enhance the enjoyment of wild birds. Establishing a designated feeding area makes many birds easier to see and photograph and, when combined with the right habitats described above, can improve the attractiveness of a yard. Below are tips for incorporating bird-feeding into a landscaping scheme, as well as how to minimize some of the pitfalls that go along with feeding birds in a yard.

Placement is important. Put feeders far enough from dense cover so cats and other predators can't easily pounce on birds. At the same time, feeders should be close enough to vegetation so birds don't waste energy flying back and forth from the feeder every time they're startled. Finding the correct balance is key; a non-vegetated area won't attract many birds, so grasses, bushes, and trees are needed nearby. But if dense plantings are too close, they might put the birds at greater risk to predators. A good happy medium is to have some shrubs or low trees about five feet away. Also think about positioning feeders out of the path of prevailing winds whenever possible.

\section{Enjoy watching birds while minimizing risk of injury.}

Ideally, feeders should be placed where birds can be easily seen without compromising their safety. Common risks associated with feeding birds include collisions with windows, increased exposure to predators and possible disease transmission or contraction from moldy seeds or dirty feeders. Follow the guidelines for minimizing these risks described in Table 2.
Attracting hummingbirds. Hummingbirds are a favorite of many homeowners, and hummingbird feeders easily draw them into a yard. For best results, place feeders near the birds' natural nectar sources in the garden, as well as near a prominent window for optimal viewing. Hummingbird food is easy to prepare; mix four parts water to one part table sugar and boil the solution to eradicate any mold or bacteria. Allow the food to cool to room temperature, fill the feeder, and place any extra food in the refrigerator. Do not use dye in the food; it is potentially harmful to the birds and unnecessary, the bright red color on the feeder itself will attract hummingbirds. Clean the feeder frequently with a mild bleach solution and remove any bleach residue with vinegar to keep the holes open.

Keep season in mind. Winter is generally the most popular time of year for feeding birds. Cold weather and snowfall that make food both critically important and hard to find bring birds to backyard feeders. At this time, suet is an excellent addition to the bird-feeding repertoire. Suet, which can be purchased at just about any place that sells backyard bird food, is a cake of hard fat mixed with seeds, grains, nuts, and fruit. Suet is a popular food for feeding birds because the fat used to create the cakes is a highly concentrated form of energy essential to maintaining body heat. As a result, a far greater diversity of birds can be attracted, including many species, such as warblers, that don't normally attend feeders. And the setup is easy; just place the suet inside a specially designed wire rack that is easy to open and close for preparation and cleaning.

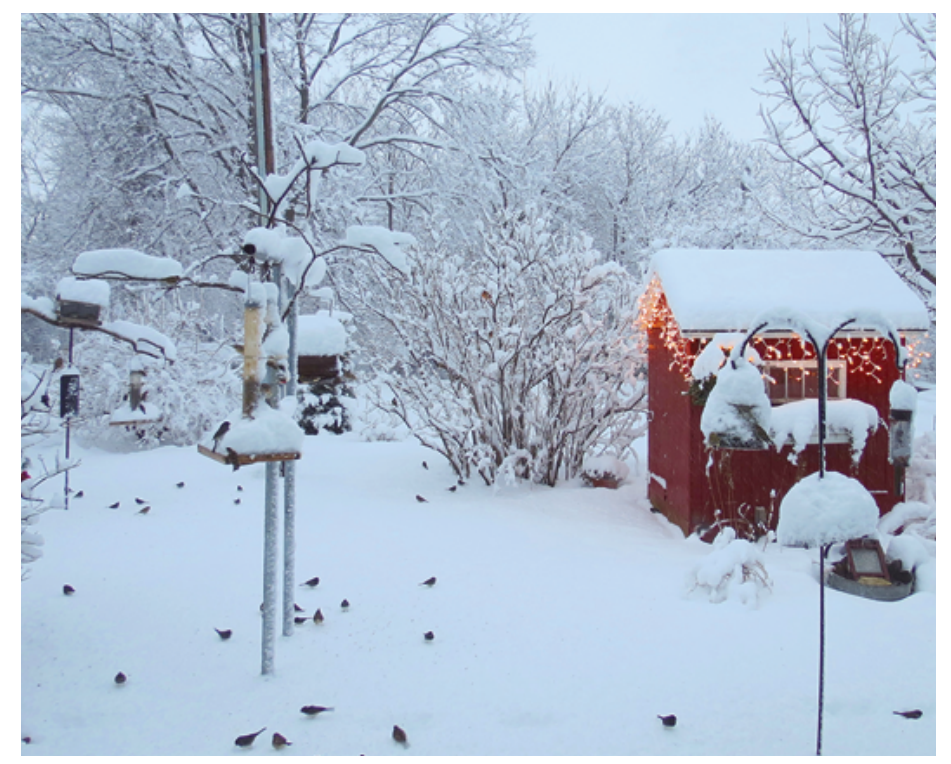

A yard that includes a diversity of native plants and an assortment of feeders kept full of food will be brimming with birds year-round, even in the snowiest of lowa winters. Photo by Karl Jungbluth. 
Table 2. Hazards of feeding birds - and solutions

\begin{tabular}{|c|c|}
\hline Hazard & Solution \\
\hline Window collisions & $\begin{array}{l}\text { Place feeders far away from windows. If feeders must be near a window, put them } \\
\text { as close as possible to the window (less than one foot away), or use specially } \\
\text { designed window and ledge feeders to keep the birds close-up. This will help keep } \\
\text { any collisions with the window at low-speed when the birds are landing or taking } \\
\text { off. Put plastic or nylon netting over adjacent windows, using a small enough mesh } \\
\text { (between } 1 / 2 \text { and } 1 \text { inch) so that birds cannot slip through the net. Coverings must } \\
\text { be on the outside of the glass to rid the window of reflection. }\end{array}$ \\
\hline $\begin{array}{l}\text { Congregations of exotic } \\
\text { birds like European starlings } \\
\text { and house sparrows }\end{array}$ & $\begin{array}{l}\text { Eliminate or greatly reduce use of cracked corn and peanut hearts, or offer these } \\
\text { foods separately from the primary feeders to draw unwanted birds away; fill any } \\
\text { holes on a house, shed, or other outbuildings to discourage nesting; avoid dense } \\
\text { shrubbery (e.g., Japanese yews) and brush piles right next to feeders. }\end{array}$ \\
\hline Transmission of diseases & $\begin{array}{l}\text { Clean feeders at least once every two weeks (or more during times of heavy } \\
\text { activity); place feeder components in a dishwater or hand wash with either a } 10 \\
\text { percent non-chlorine bleach solution or a simple mixture of soap and hot water. Use } \\
\text { vinegar to remove any bleach or soap residue. }\end{array}$ \\
\hline $\begin{array}{l}\text { Contamination of foods with } \\
\text { mold and associated toxins, } \\
\text { like aflatoxins }\end{array}$ & $\begin{array}{l}\text { Regularly inspect feeders and replace any moldy food. Clean feeders at least } \\
\text { once every two weeks. Reduce or eliminate corn, as it is the most likely to be } \\
\text { contaminated with aflatoxin, or place it far away from other bird-feeding stations. }\end{array}$ \\
\hline $\begin{array}{l}\text { Predation from hawks, feral } \\
\text { cats, and other mammals }\end{array}$ & $\begin{array}{l}\text { Fences, shepherd's posts and placing feeders about five feet away from dense } \\
\text { shrubs can help keep problematic mammals away from feeders. Cats have a keen } \\
\text { ability to kill native birds in back yards, so caution should be taken. It is almost } \\
\text { inevitable that raptors, especially Cooper's hawks and sharp-shinned hawks, will } \\
\text { occasionally swoop in and target birds at the feeders. While some observers find } \\
\text { this bothersome, others ultimately enjoy the added dimension of wildlife-watching. } \\
\text { A pragmatic way to mitigate their potential impact is to provide a variety of feeders } \\
\text { and an abundance of cover for birds to quickly escape to throughout the yard. }\end{array}$ \\
\hline
\end{tabular}

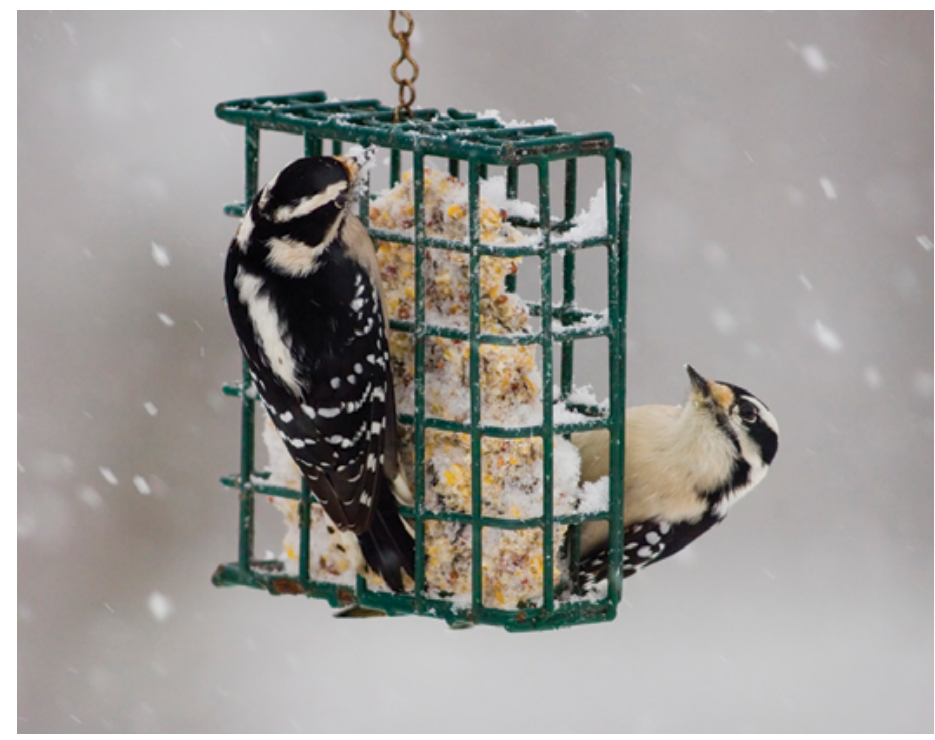

Downy woodpeckers. Photo by EEI_Tony/Thinkstock.com.
Feeder and food variety is essential. Use an assortment of feeder types mounted at multiple levels and provide a range of food types. The more diverse feeder setup and food offerings are, the more diverse backyard birds will be. Examples of feeders include hopper feeders, tube feeders, and platform feeders. Types of food sources are important too. Among the best foods for lowa are white proso millet, black-oil sunflower, safflower, nyjer (thistle seed), whole peanuts, peanut butter, suet, nectar (sugar water), orange halves, and grape jelly. The types of birds visiting a yard and the food preferences of those birds vary during the year, so make sure to maintain a variety of options. See Table 3 for a full accounting of the best types of foods to offer during different seasons and to attract different birds. 
Table 3. Best backyard bird foods and key species they attract in lowa

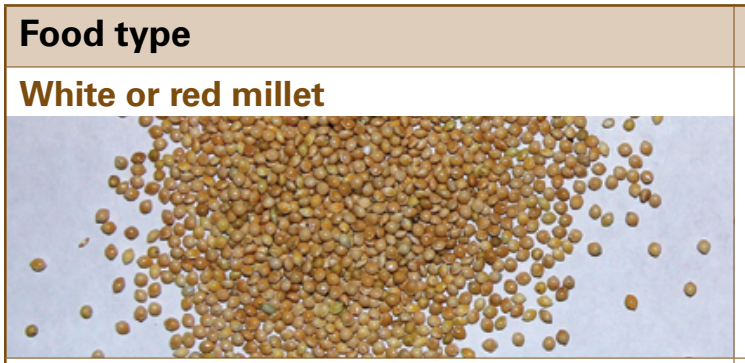

\section{Bird species}

Northern bobwhite, mourning dove, spotted towhee, eastern towhee, American tree sparrow, chipping sparrow, clay-colored sparrow, fox sparrow, song sparrow, Lincoln's sparrow, swamp sparrow, white-throated sparrow, Harris's sparrow, white-crowned sparrow, dark-eyed junco, indigo bunting
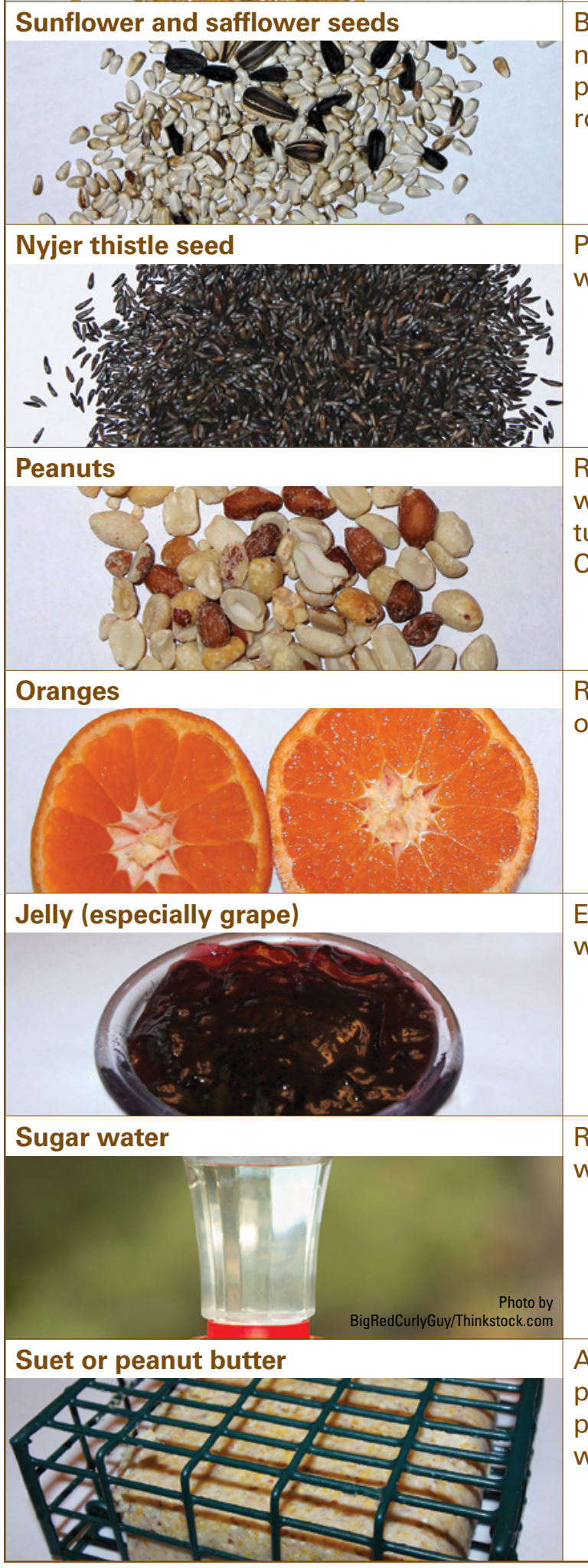

Blue jay, black-capped chickadee, tufted titmouse, red-breasted nuthatch, white-breasted nuthatch, American goldfinch, house finch, purple finch, white-winged crossbill, red crossbill, northern cardinal, rose-breasted grosbeak

Pine siskin, American goldfinch, house finch, purple finch, whitewinged crossbill, red crossbill, common redpoll, indigo bunting

Red-headed woodpecker, red-bellied woodpecker, downy woodpecker, hairy woodpecker, blue jay, black-capped chickadee, tufted titmouse, red-breasted nuthatch, white-breasted nuthatch, Carolina wren, brown thrasher, summer tanager, scarlet tanager

Red-bellied woodpecker, downy woodpecker, hairy woodpecker, orange-crowned warbler, Baltimore oriole, orchard oriole

Eastern bluebird, gray catbird, northern mockingbird, cedar waxwing, Baltimore oriole, orchard oriole

Ruby-throated hummingbird (and sometimes their rarer relatives who occasionally wander into lowa) and Baltimore oriole

A large number of birds have been documented eating suet or peanut butter in lowa, including birds not listed above, such as pileated woodpecker, brown creeper, hermit thrush, and various warblers. 
Dealing with house sparrows. If feeding birds, you'll always contend with the house sparrow, a non-native species that notoriously drives off other birds and congregates in large numbers. Fortunately, options exist to reduce its impact. One way is to eliminate or greatly reduce the use of cracked corn, one of the house sparrow's favorite foods. This food can also be presented separately from the main feeders to draw these unwanted birds away. Additionally, ornamental shrubs, particularly Japanese yew (Taxus cuspidata), function as a roosting and loafing spot for house sparrow flocks, so remove these plants when possible, especially near feeders. Likewise, man-made brushpiles also serve as a place for house sparrows to land before and after attending a feeder. Choose native grasses and shrubs instead.

\section{Exercise caution in choosing commercial seed mixes as} some include filler seeds like milo, sorghum, or wheat, which can attract unwanted guests like rodents and house sparrows or germinate under feeders during summer. Placing a single seed type on a specific feeder is an effective way to entice desirable birds and keep unwanted species at bay. Examples include putting nyjer seed in specially designed tubes for finches or spreading sunflower or safflower seeds on platform feeders to attract a wide variety of birds such as chickadees, nuthatches, cardinals, grosbeaks, and finches.

\section{Use old foods from the pantry to attract birds. Many} foods in kitchen pantries can attract unique birds. Orange halves and old jelly attract fruit-eating birds like Baltimore and orchard orioles, most notably during spring when these birds have just returned from their wintering grounds in the tropics. Place the orange halves on a commercially made

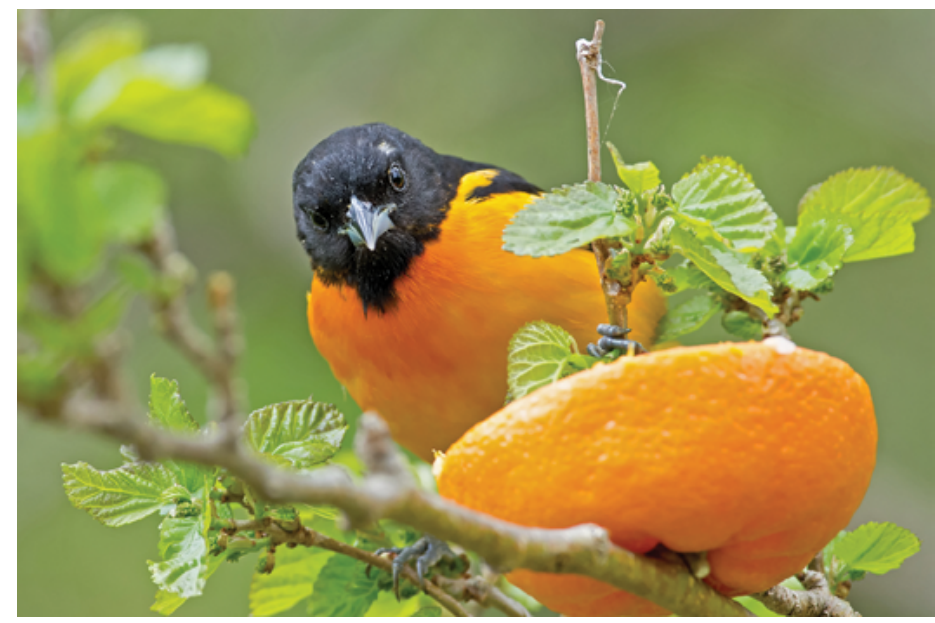

Baltimore oriole. Photo by McKinneMike/Thinkstock.com.

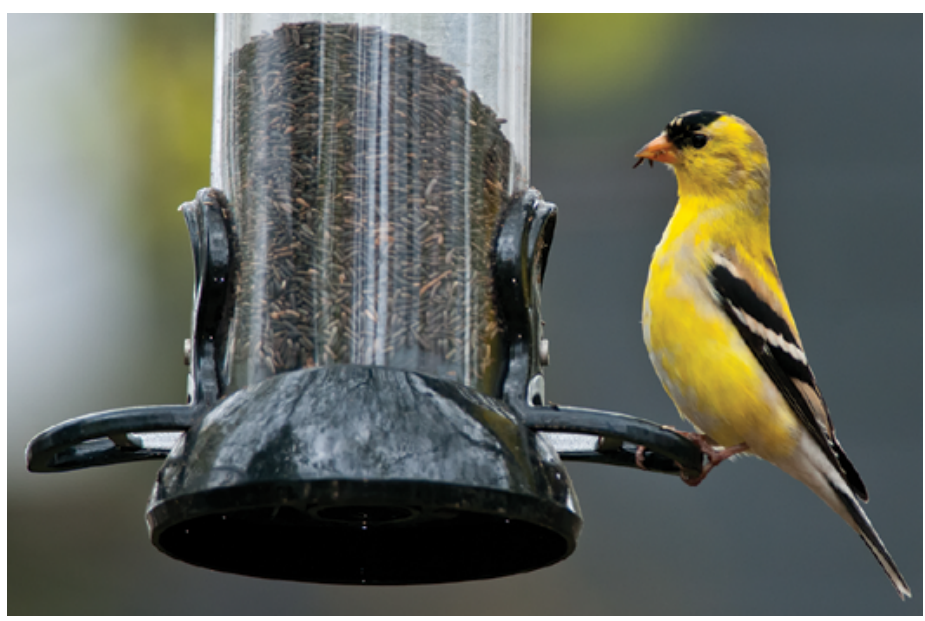

American goldfinch. Photo by PaulReevesPhotography/ Thinkstock.com.

oriole feeder or simply use a headless nail to attach the halves to a branch or elevated board which is at least three feet off the ground. Offer jelly (especially grape) in shallow cups, bowls, or specialized feeders at a similar height. A repurposed tealight candle sconce works perfectly. When orioles have shifted their diet to insects in late spring and summer, other species like gray catbird, cedar waxwing, and various woodpeckers continue to dine on the oranges and jelly.

Peanut butter is also a nearly universal treat for birds. In addition to customary feeder attendees like chickadees and nuthatches, diverse groups like warblers and thrushes also enjoy the snack. It can be presented in a wide range of settings: on traditional seed feeders, suet racks, tree branches, boards, dishes, pinecones, platforms, or just about any place where it can be safely accessed by hungry birds.

Limiting European starlings. To keep European starling numbers down, eliminate peanut hearts. Peanut hearts are what remains after the peanut embryos have been removed during the manufacturing of peanut butter. Thus, peanut hearts have diminished nutritional content, and they are less attractive to most birds, except for starlings, which are drawn to them. A yard may go from starling-free to a starling free-forall if a large number of peanut hearts are available. Closing any openings or cracks on a house, shed or other outbuildings also makes a yard less attractive for starlings, because they use these cavities for nesting. 


\section{Additional references}

\section{lowa State University Extension and Outreach - Wildlife Program}

www.nrem.iastate.edu/wildlife

Find more resources on wildlife and wildlife habitat in urban and rural environments.

\section{lowa Living Roadway Trust Fund Native Plants Database}

https://secure.iowadot.gov/Irtf/NativePlantPublic.aspx

The lowa Department of Transportation has a comprehensive database of information on plants native to lowa, their preferred site characteristics, blooming period, and typical range within the state that can serve as a useful reference for choosing native landscape plants.

\section{The Cornell Lab of Ornithology}

www.birds.cornell.edu/AllAboutBirds and

http://feederwatch.org

Resources for learning about North American birds and to find articles about feeding strategies for birds and landscaping to attract birds.

\section{Birds in lowa}

By Kent and Dinsmore (1996)

The definitive resource on the distribution and migration patterns of birds seen in lowa based on historical records and experiences of the authors.

\section{Birdscaping in the Midwest: A Guide to Gardening with Native Plants to Attract Birds}

Nowak and Raven (2012) University of Wisconsin Press

Helpful guidebook on practices for attracting birds to landscapes in the Midwest with native plant landscaping.

This publication was updated and revised by Shane Patterson, wildlife communications specialist, and Adam Janke, assistant professor and extension wildlife specialist, lowa State University Extension and Outreach. This publication built on work by Georgia Bryan, former ISU Extension and Outreach associate, and James Pease, former ISU Extension and Outreach wildlife specialist. Karl Jungbluth provided extensive guidance on the landscaping information in this publication. Digital graphics were initially developed by Rex Heer of ITC-Creative Services and updated by Alison Peters, graphic design student at lowa State University. 